\title{
Karakteristik Material Pembentuk Reclaimed Asphalt dari Jalan Nasional di Provinsi Jawa Timur
}

\author{
Characteristics of Reclaimed Asphalt Material from National Road in \\ East Java Province
}
Ari Widayanti ${ }^{1, a)}$, Ria Asih Aryani Soemitro ${ }^{2, b)}$, Januarti Jaya Ekaputri ${ }^{3, c)}$ \& Hitapriya Suprayitno ${ }^{4, d)}$

1) Mahasiswa Teknik Sipil, Institut Teknologi Sepuluh Nopember Surabaya

${ }^{2)}$ Departemen Teknik Sipil, Institut Teknologi Sepuluh Nopember Surabaya

${ }^{3)}$ Departemen Teknik Sipil, Institut Teknologi Sepuluh Nopember Surabaya

4) Departemen Teknik Sipil, Institut Teknologi Sepuluh Nopember Surabaya

Koresponden : a)ariwidayanti1973@gmail.com, ${ }^{\text {b) }}$ soemitroraa@gmail.com, ${ }^{\text {c) }}$ januartije@ gmail.com, $\&{ }^{\text {d) }}$ suprayitno.hita@gmail.com

\begin{abstract}
ABSTRAK
Jalan merupakan salah satu aset infrastruktur yang sangat penting dalam memperlancar arus distribusi barang dan pergerakan masyarakat. Pembangunan infrastruktur yang meningkat dewasa ini membutuhkan material yang meningkat pula, perlu diimbangi dengan alternatif material lain yang tersedia di alam. Reclaimed Asphalt merupakan material yang dihasilkan dari pengupasan konstruksi perkerasan jalan. Penambahan lapis perkerasan akan menyebabkan elevasi jalan semakin meningkat, sehingga kondisi permukaan jalan semakin tidak ideal. Volume Reclaimed Asphalt yang semakin menumpuk, dan pemanfaatan yang belum optimal merupakan hal yang perlu mendapat perhatian saat ini. Metode yang digunakan adalah metode studi literatur dari peneliti terdahulu pada pada jalan nasional di Provinsi Jawa Timur. Hasil yang diperoleh adalah karakteristik agregat Reclaimed Asphalt memenuhi syarat Spesifikasi Bina Marga Tahun 2010 Revisi 3, sedangkan parameter penetrasi dan daktilitas aspal Reclaimed Asphalt tidak memenuhi persyaratan. Untuk itu perlu adanya penambahan material baru untuk mengantisipasi kelemahan yang terjadi sehingga dapat memenuhi spesifikasi teknis material perkerasan jalan.
\end{abstract}

Kata Kunci : manajemen aset infrastruktur, jalan, reclaimed asphalt, material, perkerasan, jalan.

\section{PENDAHULUAN}

Salah satu aset infrastruktur yang sangat mendapat perhatian dewasa ini adalah jaringan transportasi berupa jalan raya. Jalan merupakan salah satu aset yang dimiliki oleh suatu daerah dalam menunjang perekonomian sehingga jalan mempunyai peran yang sangat penting dan strategis. Infrastruktur jalan berfungsi sebagai prasarana sistem distribusi lalu lintas barang dan manusia, sebagai prasarana pembentuk struktur ruang wilayah. Jalan merupakan tempat bergantung bagi perkembangan ekonomi dan sosial, dan prasyarat berlangsungnya berbagai aktivitas yang terjadi di masyarakat (Handayani, 2016).

Manajemen aset infrastruktur jalan sangat diperlukan dalam rangka menunjang pelayanan yang maksimal dari jalan raya sebagai penunjang dalam pergerakan masyarakat dan distribusi barang. Pembangunan yang marak dewasa ini dilakukan juga dalam rangka 
melancarkan arus distribusi orang dan barang, sehingga dapat mengurangi jarak, waktu dan biaya yang berdampak pada peningkatan kualitas hidup masyarakat. Pembangunan infrastruktur membutuhkan material yang meningkat pula, perlu diimbangi dengan alternatif material lain yang tersedia di alam.

Dengan adanya perkembangan lalu lintas yang terjadi akhir-akhir ini maka perkerasan jalan mengalami perubahan seiring dengan bertambahnya umur pelayanan jalan, kondisi cuaca dan lingkungan, serta perkembangan beban lalu lintas yang terjadi baik dari jenis kendaraan maupun volume lalu lintas. Bila lapisan perkerasan mencapai Indeks Permukaan Akhir, yang berarti perkerasan dapat dianggap sudah tidak memiliki nilai struktural lagi, maka perlu dilakukan overlay/pelapisan ulang dengan perkerasan baru. Hal ini mengakibatkan bertambahnya elevasi jalan akibat proses pelapisan yang berulang-ulang (Suwantoro, 2010).

Aspal sebagai bahan yang tidak dapat diperbaharui sehingga penggunaannya perlu dihemat seefisien mungkin. Reclaimed Asphalt merupakan hasil dari pengupasan perkerasan jalan dengan Cold Milling Machine. Reclaimed Asphalt berpotensi sebagai pengganti aspal dan agregat baru dalam perkerasan jalan, sehingga dapat menghemat sumber daya alam, mengurangi laju kerusakan alam akibat penambangan, menghemat anggaran pembangunan. Penyelenggara jalan di Provinsi Jawa Timur sejak 2006 telah menggunakan Cold Milling Machine dalam penanganan kerusakan jalan dan menghasilkan volume pekerjaan $50.000 \mathrm{~m}^{3}$ pertahun (Budianto, 2009). Reclaimed Asphalt juga berpotensi sebagai sumber limbah jika dibiarkan menumpuk dan tidak dimanfaatkan secara optimal dan akan menjadi sesuatu yang merusak lingkungan. Pemanfaatan material yang merupakan limbah bagi lingkungan perlu lebih dioptimalkan, sehingga menghemat penggunaan material alam menuju tercapainya Sustainable Development.

Perbaikan jenis kerusakan seperti retak, gelombang, alur dan lain-lain dibutuhkan pengupasan lapisan aspal lama sebelum dapat dilapis kembali. Jenis pemeliharaan jalan berpotensi mengubah elevasi jalan yaitu Preservasi (Rutin/Rehabilitasi/Berkala/Rekonstruksi/Peningkatan Struktur Jalan) sehingga menimbulkan pengerukan. Pengerukan terjadi di atas lapisan pondasi atas yaitu pada lapisan AC-WC (Asphalt Concrete - Wearing Course). Berangkat dari kenyataan kecenderungan melimpahnya Reclaimed Asphalt yang belum dimanfaatkan secara optimal, maka tinjauan terhadap karakteristik material pembentuk Reclaimed Asphalt sangat diperlukan. Selain itu juga perlu dilakukan evaluasi terhadap kelemahan dan kekuatan yang ada pada karakteristik material Reclaimed Asphalt sehingga bisa diantisipasi dalam perkembangan penelitian berikutnya.

Penulisan artikel ini bertujuan untuk:

1. Memperoleh karakteristik material pembentuk Reclaimed Asphalt,

2. Memperoleh strategi pemanfaatan Reclaimed Asphalt sebagai bahan konstruksi jalan.
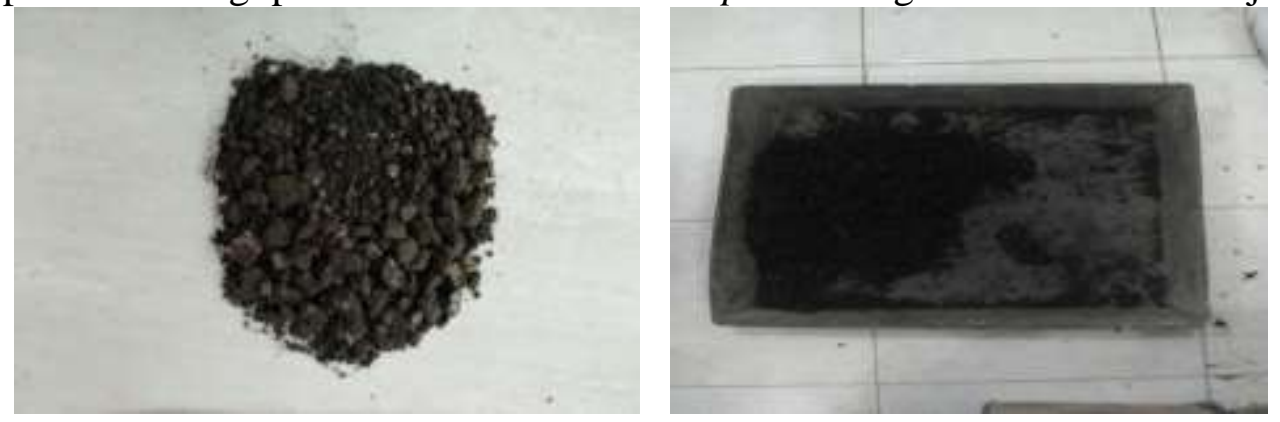

Gambar 1. Reclaimed Asphalt Pavement 


\section{STUDI PUSTAKA}

Reclaimed Asphalt adalah material hasil pengupasan dan atau pemrosesan ulang perkerasan yang terdiri atas aspal dan agregat dengan menggunakan Cold Milling Machine. Reclaimed Asphalt berpotensi dapat menghemat sumber daya alam, mengurangi laju kerusakan alam akibat penambangan, menghemat anggaran pembangunan (Budianto, 2009). Terdapat 2 sumber dari Reclaimed Asphalt yaitu reclaimed asphalt concrete (RAC) dan recycled asphalt shingles (RAS). Reclaimed Asphalt dibentuk dari lumps dan pengerukan. RAS dapat diperoleh sebagai limbah konstruksi atau berasal dari industri AMP yang telah berakhir. Untuk membentuk campuran baru, dapat dilakukan dengan atau tanpa penambahan agregat baru.

Reclaimed Asphalt dapat diproses dengan cara ekstraksi sehingga menghasilkan dua material yang berupa agregat Reclaimed Asphalt dan aspal Reclaimed Asphalt. Reclaimed Asphalt dapat dicampurkan dengan material yang lain sehingga dapat menghasilkan material yang lebih baik atau sesuai dengan kondisi aslinya. Penambahan material baru dapat memperbaiki umur teknis dan kualitas dari aspal. Pengurangan persentase dengan aspal baru atau emulsi untuk desain campuran baru digunakan kembali untuk memanfaatkan Reclaimed Asphalt sebagai material konstruksi jalan raya.

Beberapa hasil penelitian dari peneliti terdahulu dapat mengungkapkan hal-hal yang menarik perhatian tentang Reclaimed Asphalt sebagai material perkerasan jalan. Pengujian terhadap sifat dasar Reclaimed Asphalt dengan mencampurkan Reclaimed Asphalt dengan bahan tambah kapur. Diperoleh kadar aspal hasil ekstraksi Reclaimed Asphalt sebesar 4,16\%. Penambahan kapur sebesar 4,5\%. Dari hasil pengujian diperoleh properties campuran dapat ditingkatkan dengan rekayasa gradasi dan penambahan kapur (Astuti dkk, 2015).

Penggunaan Reclaimed Asphalt dengan persentase 20\%, penambahan filler fly ash sebesar 4\%, 5\%, 6\%. Dari hasil penelitian penggunaan Reclaimed Asphalt 20\% dengan hasil kinerja campuran yang paling optimal adalah dengan nilai filler 5\% dapat menghasilkan flow, stability Marshal yang sesuai dengan standar Spesifikasi Teknis Bina Marga Revisi 3 (Handayani, 2016). Penggunaan Reclaimed Asphalt sebesar 25\% dapat memenuhi persyaratan AC-WC gradasi kasar yang menghasilkan KAO sebesar 6\% dengan aspal Pen 60-70 dan 5,9\% dengan aspal Modifikasi jenis TRS 55 (Harahab dkk, 2013). Komposisi 20\% Reclaimed Asphalt dari Jalan Pilang-Probolinggo, 6,5\% agregat kasar, 25\% agregat sedang, 45\% agregat halus dan $1 \%$ semen dalam campuran beraspal panas dengan aspal modifikasi dapat memenuhi persyaratan lapisan aspal beton dengan KAO 5,6\% dengan aspal Elastomer Sintetis dan 6,2\% dengan aspal Asbuton yang Diproses (Herawati dkk, 2012).

Pencampuran awal dengan 40\% Reclaimed Asphalt dan 60\% material baru dengan pertimbangan efek ageing. Komposisi optimal diperoleh 30\% Reclaimed Asphalt Gemekan Jombang dan $70 \%$ material baru dengan KAO sebesar 5,70\%. Sedangkan 20\% Reclaimed Asphalt dan 80\% material baru dengan KAO 5,9\% (Kusmarini dkk, 2012). Komposisi 25\% Reclaimed Asphalt Jalan Pandaan-Malang dan $75 \%$ material baru dengan nilai abrasi sebesar 19,73\% memenuhi persyaratan spesifikasi Bina Marga dengan KAO sebesar 6,35\% (Falevi, 2013).

Penggantian material granular dengan 100\% Reclaimed Asphalt menghasilkan nilai tertinggi pada ITS/Indirect Tensile Strength dan resilient modulus baik pada kondisi kering maupun basah. Kondisi yang diperbandingkan adalah dengan aspal Pen 60/70 dan 80/100, dan yang lebih baik adalah menggunakan aspal Pen 80/100 (Ortiz dkk, 2012). Perbandingan Reclaimed Asphalt antara 0\%, 10\%, 20\%, 30\%, 40\%, 100\% dan bahan alam untuk hotmix asphalt dengan menggunakan Aspal Pen 60/70. Hasil penelitian ini menunjukkan persentase Reclaimed Asphalt sebesar 30\% menghasilkan nilai stabilitas yang tinggi, dan pada pihak lain menambah kemungkinan efek brittle pada campuran perkerasan jalan raya (Parvezz dkk, 2008). 
Penambahan Reclaimed Asphalt sebesar 20\% memperbaiki semua properties dari campuran aspal Penambahan Reclaimed Asphalt lebih menghasilkan kinerja yang lebih baik dibandingkan dengan hanya menggunakan agregat natural (Pradyuma dkk, 2013). Penggunaan 30-48\% Reclaimed Asphalt menunjukkan kinerja campuran yang lebih baik (volumetric properties, mechanical dan performance properties) dibandingkan dengan menggunakan bahan alami (Shen dkk, 2007).

Penelitian di laboratorium dengan menggunakan persentase Reclaimed Asphalt sebesar $10 \%, 20 \%, 30 \%, 40 \%$. Tidak ada konsistensi perubahan penambahan pada physical properties (penetrasi, duktilitas, titik lembek) pada campuran. Rentang penggunaan Reclaimed Asphalt dalam 10-40\% bisa diadopsi untuk digunakan untuk jalan baru dengan menggunakan Reclaimed Asphalt (Sunil dkk, 2014). Penambahan persentase Reclaimed Asphalt pada campuran yang berisi limbah ban, menunjukkan nilai stabilitas yang lebih tinggi. Penambahan Reclaimed Asphalt dengan limbah ban menghasilkan nilai workability yang baik. Penambahan limbah ban dapat meningkatkan ketahanan untuk dapat menahan deformasi akibat beban lalu lintas (Xiao dkk, 2009).

Penambahan Reclaimed Asphalt sebesar 25\% dengan variasi limbah ban dapat menambah nilai resilient modulus pada variasi temperatur. Penambahan ini juga direkomendasikan untuk daerah dengan iklim tropis yang bersuhu tinggi. Penambahan Reclaimed Asphalt dan limbah ban mempengaruhi umur teknis suatu jalan dan ketahanan terhadap kelelahan (Xiao dkk, 2007).

Penelitian-penelitian tersebut mengulas tentang aplikasi Reclaimed Asphalt Pavement di beberapa negara dengan persentase penggunaan dari 0\% sampai dengan $100 \%$ tergantung pada sumber dari Reclaimed Asphalt Pavement dan bagian dari lapisan perkerasan jalan raya. Dalam hal ini di Indonesia, karakteristik material berupa agregat dan kasar didasarkan pada Spesifikasi Teknis Bina Marga Revisi 3 Tahun 2010 seperti pada Tabel 1, Tabel 2, Tabel 3.

Tabel 1. Ketentuan Agregat Kasar

\begin{tabular}{|c|c|c|c|c|}
\hline \multicolumn{3}{|c|}{ Pengujian } & Standar & Nilai \\
\hline $\begin{array}{l}\text { Kekekalan } \quad \mathrm{b} \\
\text { terhadap larutan }\end{array}$ & ntuk agregat & $\begin{array}{l}\text { Natrium Sulfat } \\
\text { Magnesium } \\
\text { Sulfat }\end{array}$ & SNI 3407-2008 & $\begin{array}{l}\text { Maks. } 12 \% \\
\text { Maks. } 18 \%\end{array}$ \\
\hline $\begin{array}{lr}\text { Abrasi } & \text { dengan } \\
\text { mesin } & \text { Los } \\
\text { Angeles } & \end{array}$ & $\begin{array}{l}\text { Campuran AC } \\
\text { Modifikasi } \\
\text { Semua jenis } \\
\text { campuran aspal } \\
\text { bergradasi } \\
\text { lainnya }\end{array}$ & $\begin{array}{l}100 \text { putaran } \\
500 \text { putaran } \\
100 \text { putaran } \\
500 \text { putaran }\end{array}$ & SNI 2417-2008 & $\begin{array}{l}\text { Maks. 6\% } \\
\text { Maks. 30\% } \\
\text { Maks. } 8 \% \\
\text { Maks. } 40 \%\end{array}$ \\
\hline Kelekatan agreg & t terhadap aspal. & & SNI 2439-2011 & Min. 95\% \\
\hline Butir pecah pado & agregat kasar. & & SNI 7619-2012 & 95/90 *) \\
\hline Partikel pipih da & lonjong. & & $\begin{array}{l}\text { ASTM D4791 } \\
\text { Perbandingan } 1: 5\end{array}$ & Maks. 10\% \\
\hline Material lolos ay & kan No. 200 & & SNI 03-4142-1996 & Maks. $2 \%$ \\
\hline
\end{tabular}

Sumber: Bina Marga (2010)

Fraksi agregat kasar untuk rancangan campuran adalah yang tertahan ayakan No. 4 $(4,75 \mathrm{~mm})$. 
Tabel 2. Ketentuan Agregat Halus

\begin{tabular}{|c|c|c|}
\hline Pengujian & Standar & Nilai \\
\hline Nilai setara pasir & SNI 03-4428-1997 & Min. $60 \%$ \\
\hline Angularitas dengan uji kadar rongga & SNI 03-6877-2002 & Min. 45 \\
\hline $\begin{array}{l}\text { Gumpalan lempung dan butir-butir mudah } \\
\text { pecah dalam agregat }\end{array}$ & SNI 03-4141-1996 & Maks. $1 \%$ \\
\hline Agregat lolos ayakan No. 200 & $\begin{array}{l}\text { SNI } \\
\text { C117:2012 }\end{array}$ & Maks. $10 \%$ \\
\hline
\end{tabular}

Sumber: Bina Marga (2010)

Agregat halus harus terdiri dari pasir atau batu pecah yang lolos ayakan No. 4 (4,75 $\mathrm{mm})$.

Tabel 3. Ketentuan Aspal Keras

\begin{tabular}{|c|c|c|c|c|}
\hline \multirow[t]{3}{*}{ Jenis Pengujian } & \multirow[t]{3}{*}{$\begin{array}{l}\text { Metoda } \\
\text { Pengujian }\end{array}$} & \multirow[t]{3}{*}{$\begin{array}{l}\text { Tipe Aspal } \\
\text { Pen. 60-70 }\end{array}$} & \multicolumn{2}{|c|}{$\begin{array}{c}\text { Tipe II Aspal yang } \\
\text { Dimodifikasi }\end{array}$} \\
\hline & & & $\mathbf{A}$ & B \\
\hline & & & $\begin{array}{c}\text { Asbuton yang } \\
\text { diproses }\end{array}$ & $\begin{array}{c}\text { Elastomer } \\
\text { Sintetis }\end{array}$ \\
\hline $\begin{array}{l}\text { Penetrasi pada } 25^{\circ} \mathrm{C} \\
(0,1 \mathrm{~mm})\end{array}$ & $\begin{array}{c}\text { SNI 06-2456- } \\
1991\end{array}$ & $60-70$ & Min 50 & Min 40 \\
\hline $\begin{array}{l}\text { Viskositas Dinamis } \\
60^{\circ} \mathrm{C} \text { (Pa.s) }\end{array}$ & $\begin{array}{l}\text { SNI 06-6441- } \\
2000\end{array}$ & $160-240$ & $240-360$ & $320-480$ \\
\hline $\begin{array}{l}\text { Viskositas Kinematis } \\
135^{\circ} \mathrm{C}(\mathrm{cSt})\end{array}$ & $\begin{array}{l}\text { SNI 06-6441- } \\
2000\end{array}$ & $\geq 300$ & $385-2000$ & $\leq 3000$ \\
\hline Titik lembek $\left({ }^{0} \mathrm{C}\right)$ & SNI 24342011 & $\geq 48$ & $\geq 53$ & $\geq 54$ \\
\hline $\begin{array}{l}\text { Daktilitas pada } 25^{\circ} \mathrm{C} \\
(\mathrm{cm})\end{array}$ & SNI 24322011 & $\geq 100$ & $\geq 100$ & $\geq 100$ \\
\hline Titik nyala $\left({ }^{0} \mathrm{C}\right)$ & SNI 24332011 & $\geq 232$ & $\geq 232$ & $\geq 232$ \\
\hline $\begin{array}{l}\text { Kelarutan dalam } \\
\text { Trichloroethylene (\%) }\end{array}$ & $\begin{array}{l}\text { AASHTO T44- } \\
03\end{array}$ & $\geq 99$ & $\geq 99$ & $\geq 99$ \\
\hline Berat jenis & SNI 2441-2011 & $\geq 1,0$ & $\geq 1,0$ & $\geq 1,0$ \\
\hline $\begin{array}{l}\text { Stabilitas } \\
\text { penyimpanan } \\
\text { perbedaan titik lembek } \\
\left({ }^{0} \mathrm{C}\right)\end{array}$ & $\begin{array}{l}\text { ASTM D } 5976 \\
\text { part } 6.1\end{array}$ & - & $\leq 2,2$ & $\leq 2,2$ \\
\hline $\begin{array}{l}\text { Partikel yang lebih } \\
\text { halus dari } 150 \text { micron } \\
(\mu \mathrm{m})(\%)\end{array}$ & - & - & Min 95 & - \\
\hline \multicolumn{5}{|c|}{ Pengujian Residu hasil TFOT (SNI-06-2440-1991) atau RTFOT (SNI-03-6835-2002) } \\
\hline Berat yang hilang $(\%)$ & $\begin{array}{c}\text { SNI 06-2441- } \\
1991\end{array}$ & $\leq 0,8$ & $\leq 0,8$ & $\leq 0,8$ \\
\hline $\begin{array}{l}\text { Viskositas Dinamis } \\
60^{\circ} \mathrm{C}(\mathrm{Pa} . \mathrm{s})\end{array}$ & $\begin{array}{c}\text { SNI 03-6441- } \\
2000\end{array}$ & $\leq 800$ & $\leq 1200$ & $\leq 1600$ \\
\hline $\begin{array}{l}\text { Penetrasi pada } 25^{\circ} \mathrm{C} \\
(\%)\end{array}$ & $\begin{array}{c}\text { SNI 06-2456- } \\
1991\end{array}$ & $\geq 54$ & $\geq 54$ & $\geq 54$ \\
\hline $\begin{array}{l}\text { Daktilitas pada } 25^{\circ} \mathrm{C} \\
(\mathrm{cm})\end{array}$ & $\begin{array}{l}\text { SNI 2432- } \\
\quad 2011\end{array}$ & $\geq 100$ & $\geq 50$ & $\geq 25$ \\
\hline Keelastisan setelah & AASHTO T & - & - & $\geq 60$ \\
\hline Pengembalian $(\%)$ & $301-98$ & & & \\
\hline
\end{tabular}




\section{PENGUMPULAN DATA}

Metode pengumpulan data menggunakan metode literatur dari penelitian yang membahas tentang pemanfaatan Reclaimed Asphalt dari jalan nasional di Provinsi Jawa Timur. Untuk mendapatkan karakteristik penyusun Reclaimed Asphalt maka perlu dilakukan ekstraksi sampel untuk memisahkan aspal dan agregat. Metode pengumpulan data disampaikan pada diagram alir berikut ini.

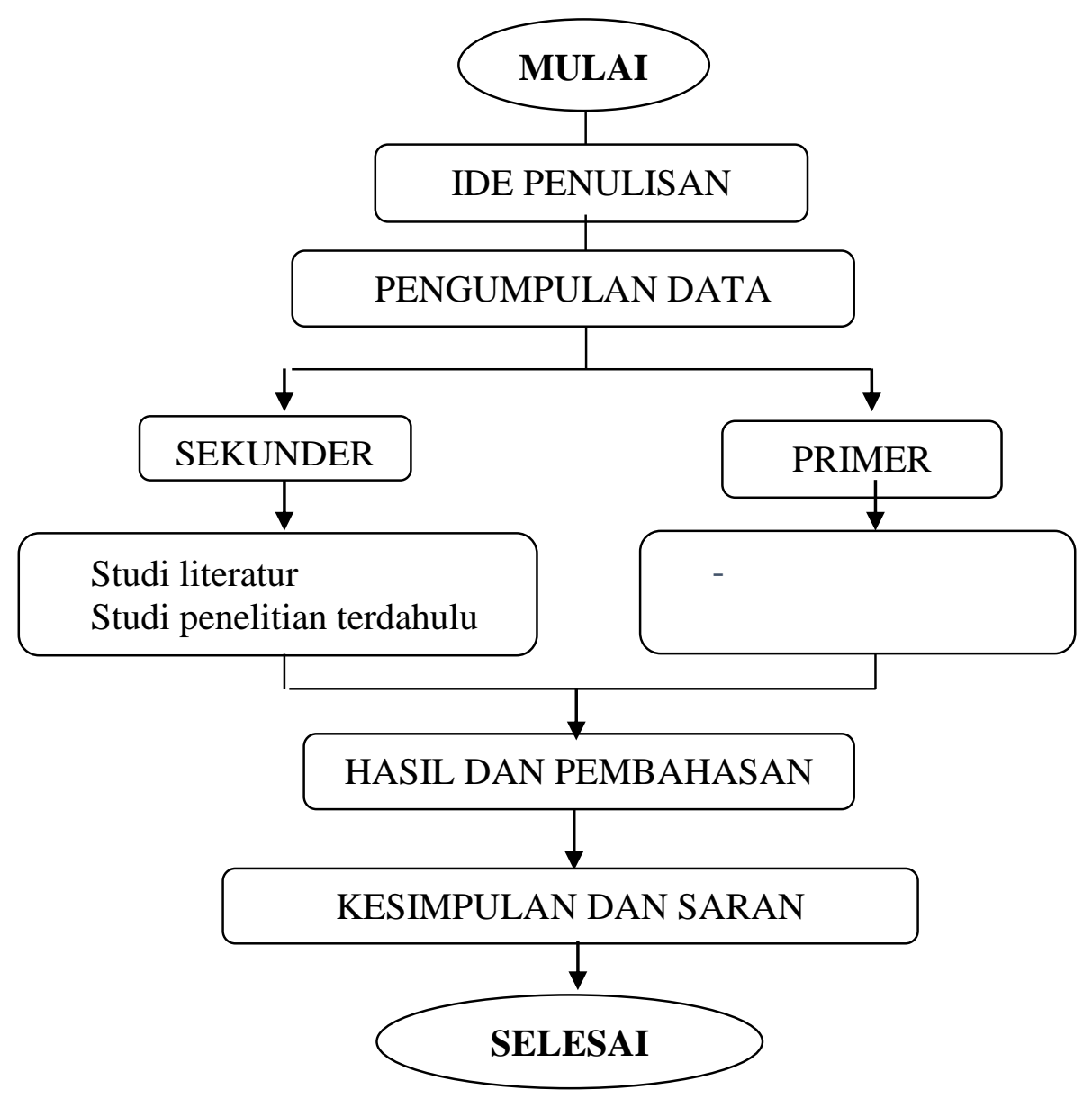

Gambar 2. Pengumpulan Data

\section{ANALISIS PENELITIAN}

Hasil yang diperoleh dari penelitian terdahulu dipresentasikan pada tabel berikut ini. Pengujian terhadap parameter aspal dan agregat merujuk pada Spesifikasi Teknis Bina Marga Tahun 2010 Revisi 3 dari material pembentuk Reclaimed Asphalt. Dari hasil penelitian tersebut diperoleh kesesuaian dan ketidak sesuaian masing-masing parameter dengan Spesifikasi Teknis Bina Marga Tahun 2010 Revisi 3. Pengujian sifat fisik material Reclaimed Asphalt dilakukan untuk mengetahui upaya- upaya yang dapat dilakukan agar penggunaannya menghasilkan campuran yang memenuhi spesifikasi. Hasil pengujian sifatsifat fisik material Reclaimed Asphalt dari dipresentasikan pada Tabel 4 berikut ini. 
Tabel 4. Karakteristik Material Pembentuk Reclaimed Asphalt

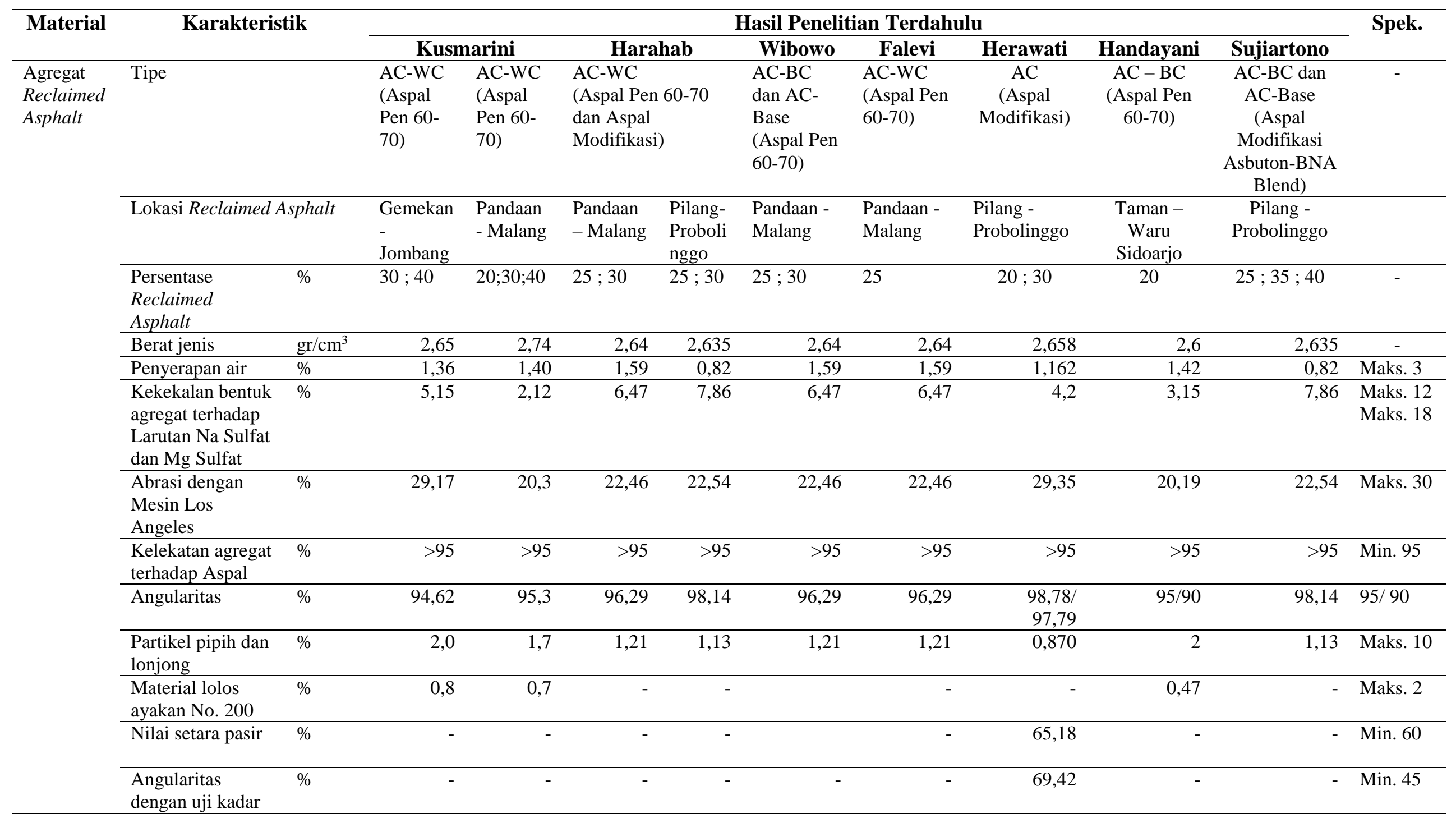




\begin{tabular}{|c|c|c|c|c|c|c|c|c|c|c|c|c|}
\hline \multirow[t]{7}{*}{ Material } & \multirow{2}{*}{\multicolumn{2}{|c|}{ Karakteristik }} & \multicolumn{9}{|c|}{ Hasil Penelitian Terdahulu } & \multirow[t]{2}{*}{ Spek. } \\
\hline & & & \multicolumn{2}{|c|}{ Kusmarini } & \multicolumn{2}{|c|}{ Harahab } & Wibowo & \multirow{2}{*}{ Falevi } & \multirow{2}{*}{ Herawati } & \multirow[t]{2}{*}{ Handayani } & \multirow[t]{2}{*}{ Sujiartono } & \\
\hline & rongga & & & & & & & & & & & \\
\hline & $\begin{array}{l}\text { Gumpalan } \\
\text { lempung dan butir } \\
\text { mudah pecah } \\
\text { dalam agregat }\end{array}$ & $\%$ & - & - & - & - & - & - & - & - & - & Maks.1 \\
\hline & $\begin{array}{l}\text { Material lolos } \\
\text { ayakan No. } 200\end{array}$ & $\%$ & - & - & - & - & - & - & - & - & - & Maks.10 \\
\hline & Berat jenis & $\mathrm{gr} / \mathrm{cm}^{3}$ & - & - & - & - & & - & 2,692 & - & - & - \\
\hline & Penyerapan air & $\%$ & - & - & - & - & & - & 0,84 & - & - & Maks. 3 \\
\hline \multirow[t]{6}{*}{$\begin{array}{l}\text { Aspal } \\
\text { RAP }\end{array}$} & $\begin{array}{l}\text { Kadar aspal } \\
\text { dalam campuran }\end{array}$ & $\%$ & 4,6 & 3,78 & 4,63 & 4,15 & 4,63 & 4,63 & 4,5 & 4 & 4,18 & - \\
\hline & $\begin{array}{l}\text { Penetrasi pada } \\
25^{\circ} \mathrm{C}\end{array}$ & $\mathrm{dmm}$ & 21 & 22 & 21 & 19 & 21 & 21 & 19 & 49 & 19 & $60-70$ \\
\hline & Viskositas $135^{\circ} \mathrm{C}$ & $\mathrm{cSt}$ & 1.440 & 1.900 & 1.950 & 2.300 & 1.950 & 1.950 & 2.450 & 2.300 & 2.300 & $\geq 300$ \\
\hline & Titik lembek & ${ }^{0} \mathrm{C}$ & 62,4 & 62,0 & 57,5 & 65,5 & 57,5 & 57,5 & 64,8 & 55 & 65,5 & $\geq 48$ \\
\hline & $\begin{array}{l}\text { Daktilitas pada } \\
25^{\circ} \mathrm{C}\end{array}$ & $\mathrm{cm}$ & 19 & 23 & 24 & 19 & 24 & 24 & 11,5 & $>120$ & 19 & $\geq 100$ \\
\hline & Berat jenis & $\mathrm{gr} / \mathrm{cm}^{3}$ & 1,060 & 1,067 & 1,056 & 1,058 & 1,056 & 1,056 & 1,066 & 1,067 & 1,058 & $\geq 1,0$ \\
\hline
\end{tabular}

Sumber: Prosiding Seminar Nasional dan Tesis ITS Surabaya. 
Tabel 4 menunjukkan bahwa pelapukan agregat selama masa pakai tidak banyak berpengaruh pada sifat fisik agregat Reclaimed Asphalt. Hal ini terlihat dari nilai kekekalan bentuk agregat setelah direndam dalam larutan magnesium sulfat dan nilai abrasi yang masih memenuhi syarat, dimana kedua nilai tersebut menunjukkan ketahanan agregat terhadap degradasi dan disintegrasi selama proses produksi dan operasi. Hal ini disebabkan adanya lapisan aspal yang telah menyelimuti agregat Reclaimed Asphalt, namun dengan kondisi ini nilai kelekatan agregat Reclaimed Asphalt terhadap aspal masih memenuhi syarat spesifikasi sehingga diharapkan masih mampu untuk menerima, menyerap dan menahan tebal aspal film sesuai dengan spesifikasi teknis. Nilai partikel pipih dan lonjong dari agregat Reclaimed Asphalt berada di bawah batas maksimum spesifikasi teknis. Hal ini menunjukkan bahwa agregat Reclaimed Asphalt mempunyai permukaan yang kasar dan bentuk kubikal. Dengan terpenuhinya karakteristik ini diharapkan campuran perkerasan jalan dengan Reclaimed Asphalt dapat mempunyai stabilitas yang tinggi karena interlocking antar agregat yang lebih besar.

Tabel 4 menunjukkan bahwa sifat fisik aspal Reclaimed Asphalt mengalami kenaikan jika dibandingkan dengan spesifikasi. Namun demikian nilai penetrasi aspal Reclaimed Asphalt berada di bawah ambang batas spesifikasi untuk jenis aspal yang digunakan, sedangkan nilai viskositas aspal Reclaimed Asphalt berada jauh di atas ambang batas minimum spesifikasi. Nilai penetrasi dan viskositas adalah karakteristik aspal yang menunjukkan tingkat kekerasan/kekakuan aspal pada suhu tertentu. Nilai penetrasi yang rendah dan nilai viskositas yang tinggi dari aspal Reclaimed Asphalt menunjukkan bahwa aspal Reclaimed Asphalt mempunyai tingkat kekerasan dan kekakuan yang tinggi. Peningkatan kekerasan dan kekakuan aspal dapat meningkatkan stabilitas campuran namun pada sisi lain menyebabkan campuran menjadi lebih getas.

Uji daktilitas adalah untuk mengetahui sifat kohesi dari aspal hasil Reclaimed Asphalt. Kohesi adalah kemampuan aspal untuk tetap mempertahankan agregat tetap pada tempatnya setelah terjadi pengikatan. Nilai daktilitas aspal Reclaimed Asphalt yang tinggi menunjukkan tingginya kohesi/kemampuan partikel aspal keras untuk melekat satu dengan yang lain sehingga dapat mengikat butir-butir agregat dengan baik. Sedangkan nilai daktilitas aspal Reclaimed Asphalt yang rendah menunjukkan rendahnya kohesi/kemampuan partikel aspal keras untuk melekat satu dengan yang lain sehingga dapat mengikat butir-butir agregat dengan baik. Hasil pengujian titik lembek aspal Reclaimed Asphalt yang berkisar 55$65,5^{\circ} \mathrm{C}$, berada di atas ambang batas minimum spesifikasi yaitu aspal Pen 60/70 yang berkisar $48^{\circ} \mathrm{C}$. Hal ini menunjukkan bahwa perkerasan dengan aspal Reclaimed Asphalt lebih tahan terhadap perubahan bentuk karena suhu tinggi di lapangan, karena aspal Reclaimed Asphalt baru mulai melunak pada suhu yang lebih tinggi. Daya lekat terhadap aspal (affinity for asphalt) dipengaruhi oleh sifat mekanis dan sifat kimiawi dari agregat. Sifat mekanis meliputi pori-pori dan absorpsi, bentuk dan tektur permukaan, ukuran butir (Sukirman, 1995). Agregat berpori baik untuk menimbulkan ikatan yang kuat antara agregat dan aspal. Tetapi jika terlalu banyak pori akan menimbulkan terlalu banyak aspal yang diserap sehingga lapisan aspal menjadi tipis. Agregat berbentuk kubus dan kasar lebih baik mengikat aspal daripada agregat berbentuk bulat dan halus. Permukaan agregat yang kasar akan memberikan ikatan dengan aspal yang lebih baik daripada agregat dengan permukaan licin.

Daya lekat terhadap aspal dipengaruhi oleh sifat agregat terhadap air. Granit dan batuan yang mengandung silika merupakan agregat yang bersifat hydrophilic yaitu agregat yang mudah terikat terhadap air. Agregat jenis ini tidak baik digunakan sebagai bahan campuran dengan aspal karena akan mudah terjadi stripping yaitu terlepasnya lapis aspal dari agregat karena pengaruh air. Kondisi sebaliknya, agregat seperti diorit -andesit disebut agregat hydrophobic adalah agregat yang tidak mudah terikat dengan air sehingga ikatan 
antara agregat dan aspal cukup baik, dan stripping yang terjadi kecil sekali. Ukuran butir agregat dihubungkan dengan amplop gradasi untuk agregat Reclaimed Asphalt.

Dengan membandingkan sifat-sifat fisik Reclaimed Asphalt terhadap spesifikasi maka dapat diperoleh hasil bahwa karakteristik agregat Reclaimed Asphalt memenuhi syarat spesifikasi terhadap semua parameter pengujian, sehingga dapat digunakan sebagai bahan campuran perkerasan jalan. Karakteristik aspal Reclaimed Asphalt memenuhi syarat spesifikasi pada parameter viskositas dan titik lembek, tetapi pada nilai penetrasi dan daktilitas aspal Reclaimed Asphalt tidak memenuhi persyaratan spesifikasi, sehingga perlu penambahan aspal baru atau material lain untuk memperbaiki sifat-sifat fisiknya.

\section{KESIMPULAN}

Dari hasil pengumpulan data dan analisis yang sudah dilakukan maka kesimpulan yang diperoleh adalah:

- Karakteristik agregat Reclaimed Asphalt memenuhi syarat spesifikasi, sehingga dapat digunakan sebagai bahan campuran perkerasan jalan. Karakteristik aspal Reclaimed Asphalt mempunyai kesesuaian pada parameter viskositas dan titik lembek, sedangkan pada parameter penetrasi dan daktilitas tidak sesuai dengan Spesifikasi Umum Bina Marga Tahun 2010 Revisi 3.

- Strategi pemanfaatan Reclaimed Asphalt sebagai bahan konstruksi jalan adalah perlu penambahan material lain yang ramah lingkungan sehingga dapat mengantisipasi kelemahan yang ada. Dalam hal ini penambahan agregat dengan tekstur yang kasar dan penambahan aspal baru perlu dilakukan untuk bisa memenuhi spesifikasi teknis yang berlaku.

Dari hasil pengumpulan data, analisis dan kesimpulan, maka saran yang bisa diberikan adalah:

- Perlu dilakukan penelitian lebih lanjut dengan pemanfaatan material lain yang dapat mengisi kelemahan dari penggunaan Reclaimed Asphalt sebagai material konstruksi jalan raya.

Catatan. Penulisan artikel ini didukung dengan beberapa studi literatur yang bertujuan untuk mengetahui karakteristik material Reclaimed Asphalt . Untuk itu kami menyampaikan banyak terima kasih kepada para peneliti yang karyanya menjadi rujukan dalam penulisan artikel ini.

\section{DAFTAR PUSTAKA}

Astuti, W.W., Sunarjono, S., Sutanto, M.H. (2015). “Analisis Pengaruh Bahan Tambah Kapur terhadap Karakterisrik RAP (Reclaimed Asphalt Pavement)”. Teknik Sipil. Universitas Muhammadiyah Surakarta.

Bina Marga. (2010). Spesifikasi Umum Bina Marga Tahun 2010 Revisi 3. Direktorat Jenderal Bina Marga Kementrian Pekerjaan Umum. Jakarta.

Budianto, H. (2009). Menuju Jalan yang Andal, PT. Cakra Daya Sakti. Surabaya.

Falevi, R. (2012). Optimalisasi Penggunaan Reclaimed Asphalt Pavement (RAP) sebagai Bahan Campuran Beraspal Panas (Asphaltic Concrete) Tipe AC-Wearing Course (ACWC) Gradasi Halus dengan Menggunakan Aspal Pen 60-70 Variasi Abrasi Agregat Baru (Studi Kasus Jalan Nasional Pandaan - Malang). Tesis Pasca Sarjana. Institut Teknologi Sepuluh Nopember Surabaya.

Handayani, R. (2016). "Analisa Penggunaan Reclaimed Asphalt Pavement (RAP) sebagai Bahan Campuran Beraspal Panas Tipe Asphalt Concrete-Binder Course (ACBC) dengan Menggunakan Fly Ash (Studi Kasus Ruas Jalan Taman Waru)". Tesis Pasca Sarjana. Institut Teknologi Sepuluh Nopember Surabaya. 
Harahab, S. Soemitro, R.A.A, Budianto, H. (2013). “Optimalisasi Penggunaan Reclaimed Asphalt Pavement (RAP) sebagai Bahan Campuran Beraspal Panas (Asphaltic Concrete) Tipe AC-Wearing Course (AC-WC) Gradasi Kasar dengan Aspal Pen 60-70 dan Aspal Modifikasi Jenis TRS 55 (Studi Kasus Jalan Nasional Pandaan-Malang dan Jalan Nasional Pilang-Probolinggo)”. Prosiding Seminar Nasional Pascasarjana XIII ITS, Surabaya 15 Agustus 2013, ISBN No. 978-979-96700-6-9.

Herawati, N., Soemitro, R.A.A., Budianto, H. (2012). "Analisis Penentuan Komposisi Optimal Penggunaan Reclaimed Asphalt Pavement (RAP) sebagai Bahan Campuran Beraspal Panas (Asphaltic Concrete) Menggunakan Aspal Modifikasi (Studi Kasus Jalan Pilang - Probolinggo)". Prosiding Seminar Nasional Aplikasi Teknologi Prasarana Wilayah (ATPW) Surabaya, 11 Juli 2012. ISSN 2301-6752, Material Bahan Bangunan dan Konstruksi, hal. F-1.

Kusmarini, E.P., Soemitro, R.A.A., Budianto, H. (2012). “Analisis Penggunaan Reclaimed Asphalt Pavement (RAP) dan Aspal Pen 60 - 70 sebagai Bahan Campuran Beraspal Panas (Asphaltic Concrete ) (Studi Kasus Ruas Jalan Gemekan - Jombang dan Pandaan - Malang)”. Prosiding Seminar Nasional Aplikasi Teknologi Prasarana Wilayah (ATPW) Surabaya, 11 Juli 2012, ISSN 2301-6752, Material Bahan Bangunan dan Konstruksi, hal. F-5 - F-10.

Ortiz, O. R. Berardinelli, A., Carvajal-M., Fuentes, L.G. (2012). "Evaluation of Hot Mix Asphalt Mixtures with Replacement of Aggregates by Reclaimed Asphalt Pavement (RAP) Material”, Procedia Sosial and Behavioral Sciences 53, hal. 379-388.

Parveez, Prateek, Srikanta, Yathiraj, Konnur, Dinesh, (2013). "Study on the Effect of Reclaimed Asphalt Pavement (RAP) on the Mechanical Behaviour of Hot Mix Asphalt", India.

Pradyumna, T Anil. Mittal, Abhishek, Jain, P.K. (2013). "Characterization of Reclaimed Asphalt Pavement (RAP) for Use in Bituminous Road Construction”, Procedia-Social and Behavioral Sciences 104, hal. 1149-1157.

Sujiartono, A. (2014). Optimalisasi Penggunaan Reclaimed Asphalt Pavement (RAP) sebagai sebagai Bahan Campuran Beraspal Panas (Asphaltic Concrete) Tipe AC-Binder Course (AC-BC) dan AC-Base Course (AC-Base) dengan Menggunakan Aspal Modifikasi Asbuton (BNA-Blend) (Studi Kasus Jalan Nasional Pilang-Probolinggo). Tesis Pasca Sarjana. Institut Teknologi Sepuluh Nopember Surabaya.

Sukirman, S. (1995). Perkerasan Lentur Jalan Raya, Penerbit Nova. Bandung.

Suwantoro (2010). Optimalisasi Penggunaan Material Hasil Cold Milling untuk Daur Ulang Lapisan Perkerasan Beton Aspal Tipe AC (Asphaltic Concrete). Tesis Pasca Sarjana. Institut Teknologi Sepuluh Nopember Surabaya.

Wibowo, H.W. (2012). Optimalisasi Penggunaan Reclaimed Asphalt Pavement (RAP) sebagai Material Campuran pada Asphaltic Concrete Tipe AC-BC dan AC-Base dengan Pen 60-70 (Studi Kasus Jalan Nasional Pandaan - Malang). Tesis Pasca Sarjana. Institut Teknologi Sepuluh Nopember Surabaya.

Xiao, F., Amirkhanian, S.N., Shen, J., Putman, B. (2009). "Influences of Crumb Rubber Size and Type on Reclaimed Asphalt Pavement (RAP) Mixtures", Construction and Building Materials 23, hal.1028-1034.

Xiao, F., Amirkhanian, Serji, J., Hsein, C. (2007). "Rutting Resistance of Rubberized Asphalt Concrete Pavements Containing Reclaimed Asphalt Pavement Mixtures", Journal of Materials in Civil Engineering, ASCE, June 2007, hal. 475-483.

Shen, J., Amirkhanian, S., Aune, J.M. (2007). "Effects Of Rejuvenatin Agents Of Superpave Mixtures Containing Reclaimed Asphalt Pavement". Journal of Materials in Civil Engineering. ASCE. May. 2007. 
